\title{
Imanência e solução profana: correspondências históricas entre o direito natural e o Trauerspiel
}

\author{
Virgínia Juliane Adami Paulino (USP)
}

Resumo: Pretende-se, por meio desse artigo, estudar a relação entre direito e literatura, tendo como base a obra Origem do drama barroco alemão Trauerspiel, de Walter Benjamin, com o objetivo de pensar como a ideia barroca, marcada pela perda de transcendência e pela busca de solução profana, na atuação do Príncipe, influenciou tanto o séc. XVII quanto o atual, dadas as semelhanças que permitem a rememoração recíproca.

Palavras-chave: Alegoria. Direito. História. Imanência. Literatura. Modernidade.

Palavras-chave: Alegoria. Direito. História. Imanência. Literatura. Modernidade

\section{Harmonia no cosmos e na vida: o círculo como alegoria do tempo histórico}

Fixando um compasso no papel, podemos ajustar sua abertura para que comecemos o traçado. Assim, fazendo com que seu raio seja a unidade de medida temporal, o movimento será análogo à expansão ou à regressão das órbitas, como no espaço, tomando a Terra como centro. Sim, a Terra, pois não faz sentido a tentativa de compreender o tempo grego mudando suas premissas. A percepção circular da história, decorrente desse raciocínio, permite que identifiquemos nos acontecimentos a repetição, tal como, para Platão, era possível identificar no movimento de translação dos planetas sempre o mesmo sentido ${ }^{1}$.

Os gregos gostavam de observar o céu não apenas pelo espetáculo de contemplação de deuses visíveis ${ }^{2}$, mas, sobretudo, pela mímesis de uma disciplina encontrada nessa ordem externa e que pretendiam interiorizar. Como demonstra Platão ao caracterizar a areté, a partir da realização, no indivíduo, de seu próprio cosmos. ${ }^{3}$ De forma que da correspondência entre o conhecimento da astronomia (curso matemático invariável dos astros) e o de si (experiência da alma como um ser em eterno fluir), o filósofo retirou seus pilares de fundamentação da fé no divino. ${ }^{4}$

Analisando esta época a partir do enfoque da literatura, percebe-se que a harmonia mencionada anteriormente como alvo a ser alcançado nas relações humanas, repetindo o modelo celeste, é almejada também no comportamento dos personagens, na forma como a trama se desenvolve e nos sacrifícios rituais que levam ao heroísmo. Assim, o gênero literário que marcou a Grécia Antiga foi a tragédia, representada, sobretudo, por Ésquilo, Sófocles e Eurípedes, três ícones de um período no qual a poesia tinha uma carga fortemente educativa, inserida no ideal de Paideia - formação do homem grego. Encontraremos nesta época, então, diversos textos nos quais a renúncia e a sagacidade encaminham o homem para seu destino heróico, na superação daquele fado atroz, de forma que, mesmo não sobrevivendo a esta aventura, o prejuízo não seria tão grande, por ser a morte interpretada muito mais como libertação do que como catástrofe. 
Há, portanto, a preocupação de se elaborar personagens cujo comportamento sirva de exemplo à humanidade, concedendo a ela esperança em seu próprio futuro. É o que constatamos da análise de Werner Jaeger sobre o Prometeu de Ésquilo:

Prometeu é o que traz a luz à humanidade sofredora. (...) Prometeu é o espírito criador da cultura, que penetra e conhece o mundo, que o põe ao serviço da sua vontade por meio da organização das forças dele de acordo com os seus fins pessoais, que lhe descobre os tesouros e assenta em bases seguras a vida débil e oscilante do Homem. ${ }^{5}$

Neste exemplo, percebe-se que o personagem de Prometeu, por mais que tenha sido punido dolorosamente, teve êxito no seu esforço de roubar o fogo dos deuses, ajudando, por meio desse delito, todo o gênero humano, controlando a natureza, rumo ao ideal de progresso. Ainda que exista o sofrimento, ele está voltado para um fim de superação, uma etapa necessária à felicidade e ao heroísmo.

É o caso também de Sócrates, em cujo discurso de defesa perante um Tribunal que deseja sua condenação à pena capital, mostra-se sereno, não temendo minimamente a morte, alegando ser impossível temer aquilo cujas vantagens ou desvantagens desconhece. Nesse caso - relatado pelo discípulo Platão - Sócrates enfrenta seu destino, tragicamente superando-o e rompendo com o ciclo imposto pela natureza. A morte é recepcionada com harmonia: desfecho coerente para uma vida heroica, correta no cumprimento de uma missão. Transcende a existência terrena em direção a novas promessas.

\section{Equilíbrio desfeito: o Trauerspiel e a natureza sem transcendência}

Séculos mais tarde, Walter Benjamin, na Tese I de Sobre o conceito de história, ilustrou a teologia, alegoricamente, como um anão corcunda escondido debaixo da mesa, a manipular o boneco "chamado materialismo histórico", este sim visível, muito embora desprovido de movimentos próprios ${ }^{6}$. Com o eterno retorno dos temas, percebe-se que, inserida numa tradição diferente, na qual já sabemos não ser a Terra o centro do universo, a fé no divino reaparece como intuição. Mais curiosa do que essa alegoria é a forma como Benjamin comenta, em seus estudos sobre a filosofia da história, a direção do tempo, fazendo-o em um contexto no qual os instrumentos potencialmente úteis para o cálculo das órbitas estão abandonados na Terra, sem serventia ${ }^{7}$. Já não existe um céu para se imitar, na medida em que se perdeu a transcendência: a ordem interior está igualmente desfeita para o indivíduo contemporâneo, impotente diante de um destino cego, acêntrico, absurdo demais para ser compreendido matematicamente.

Essa transição anunciada por Benjamin corresponde ao Trauerspiel, gênero literário característico do século XVII, que abrange o Barroco, os dramaturgos alemães, Calderón e os elisabetanos. Difere, portanto, enormemente da concepção de tragédia própria da Grécia Antiga, principalmente devido à perda de transcendência na atuação do herói. Em outras palavras, as lutas que este protagonista precisa travar, não têm como resultado a superação. A esperança se esgota no próprio trajeto, infinitamente percorrido, sem possibilidade de fuga, pois mesmo a morte já não significa a passagem para um novo cenário e sim o recomeço daquele mesmo ciclo. Revela um sofrimento interminável, diante da supremacia do destino onipotente. 
A grande diferença, então, concentra-se na impossibilidade de apelo aos deuses, pois, se na tragédia os gregos podiam oferecer sacrifícios para apaziguar os desejos divinos sempre imprevisíveis, no Trauerspiel, contrariamente, o sacrifício é um fim em si mesmo, uma destruição inevitável do indivíduo preso em uma natureza desprovida de transcendência.

\section{Correspondências históricas: o elemento barroco no séc. XX}

$\mathrm{Na}$ Melancolia I, percebemos a face da personagem de Albert Dürer voltada para baixo, em atitude meditativa, absorvida em pensamentos que lhe carregam a expressão, de forma que seu olhar triste se volta não para o céu, mas para os utensílios da vida ativa espalhados pela terra. Temos, portanto, uma conversão significativa de objeto, nas palavras de Walter Benjamin, "[...]a Renascença investiga o universo, e o Barroco, as bibliotecas" $"$. Trata-se, assim, de uma gravura que antecipa o barroco, imprimindo-lhe uma imagem que o eterniza como alegoria, sendo que no esforço de decifrá-la, são realizados diálogos impossíveis entre os chamados períodos históricos, "[...]num encontro secreto marcado entre as gerações passadas e a nossa". 9

A partir da pintura, então, pode-se resgatar a percepção do artista sobre seu tempo, na forma como ele o assimilou. Assim procede também aquele que investiga a moda preponderante em uma determinada sociedade, em suas vestimentas e acessórios, para que consiga desprender do contexto passado elementos adaptáveis à moda atual. Por isso Benjamin comparar o desenvolvimento da História com a evolução da moda, na tese XIV sobre o conceito de história:

(...) A Revolução Francesa compreendia-se como uma Roma retornada. Ela citava a antiga Roma exatamente como a moda cita um traje do passado. A moda tem faro para o atual, onde quer que este se mova no emaranhado de outrora. Ela é o salto de tigre em direção ao passado. ${ }^{10}$

Desperte-se então o homem barroco neste início do século XXI, dada a ressonância dos efeitos do pós-guerra, mas que isso seja feito sem pretender reconstituí-lo enquanto sujeito histórico, pois sendo único o momento que permitiu sua ascensão, ao ressuscitá-lo estaríamos apenas condenando-o a uma segunda morte, uma vez que tão logo aparecessem as primeiras dificuldades para entender o passado tal como ele de fato foi, preencheríamos essa ausência inventando-o, valendo-nos, para isso, do vastíssimo material que temos disponível, qual seja, nossa própria realidade. Assim, despertaríamos o homem barroco, para moldá-lo às nossas expectativas em um processo de montagem do qual resultaria um produto precoce e imaturo de nossa própria consciência.

Rejeita-se, portanto, o olhar de identificação com o passado, já que não se pretende a repetição como freqüência histórica, não se quer defender a perpetuação do tempo como se ele de fato fosse cíclico, pelo contrário, a intenção é a de recuperar aquilo que estando preso no passado nunca conseguiu efetivação, mas guarda em si a potência de se consumar, desde que apreendido por esse novo olhar historiográfico, a saber, o método benjaminiano que se concretiza "sob o céu livre da História". 11

A diferença precisa ser insistentemente sublinhada, para que se esclareça que o vínculo com o passado pode ser firmado de duas formas principais: em primeiro lugar, a partir da identificação, como foi colocado anteriormente, dando ensejo à repetição, ao 
aprisionamento no interior de nexos causais intransponíveis. Em segundo lugar, a perspectiva de Benjamin, que se concentra no passado não para perpetuá-lo, mas para realizar promessas não concretizadas. Assim, quando for mencionado o termo repetição, é preciso que ele seja interpretado dentro dos limites hermenêuticos deste conceito benjaminiano, ou seja, voltar ao passado para se buscar algo inédito, permitindo, com isso, sua redenção.

A perspectiva da qual iremos nos afastar, segundo Benjamin, é a dos "vencedores", aqueles que tendo sido sempre beneficiados, não desejam outra coisa além da preservação deste status quo, do que decorre uma íntima relação com o culto ao progresso, afinal de contas, quer-se um olhar sempre adiante, sepultando definitivamente as contradições do passado, para que nenhuma dialética seja estabelecida, nenhum questionamento. Enfim, a história, no ponto de vista destes vencedores, deve ser mantida por laços de continuidade, ocultando-se os fragmentos e as ruptura. Trata-se de uma forte crítica ao historicismo, enquanto método de estudo que privilegia os nexos causais, como se os acontecimentos essencialmente humanos e, portanto, políticos, pudessem ser reduzidos às mesmas leis nas quais são submetidas as ciências naturais e matemáticas.

Ora, todas essas divagações benjaminianas são conseqüência da preocupação deste autor com o seu próprio tempo, no qual preponderava a concepção linear da história, grande alvo de sua crítica, também por ser compreendida como fator que leva ao conformismo. Nas Teses sobre o conceito de história (1940), por exemplo, o culto ao progresso exercido pela social-democracia é o grande mote benjaminiano, o centro de suas contra-argumentações, já que a certeza de se nadar no sentido da corrente, enfraqueceu o movimento operário alemão, impedindo que ele pudesse enxergar suas regressões, ao cultuar um futuro glorioso que chegaria por si mesmo, mas que, como se sabe, jamais se realizou.

$\mathrm{Na}$ análise precisa de Jeanne Marie Gagnebin, temos que:

Deve ser construído um segundo contexto histórico, menos uma descrição tranqüila e erudita de uma certa época e muito mais uma confrontação entre presente e passado, um questionamento não tanto sobre "aquilo que o passado teria a nos dizer", mas muito mais sobre o porquê do interesse do presente por eventos específicos do passado; esse interesse que pode até consistir na configuração de uma estratégia de fuga socialmente valorizada e bem longe dos conflitos atuais. ${ }^{12}$

Por isso assimilação deste tempo passado não se dá por acaso, por vezes, mantendo-se encoberto ao longo de séculos até enfim ressurgir como uma proposta nova, notando-se, entretanto, que se trata de uma novidade relativa, já que apenas a concretização é inovadora, não a idéia em si que esteve até então apenas escondida, obscura, até que uma contingência do presente lançou sobre ela um olhar, tornando-a evidente, garantindo, portanto, sua emergência num contexto que revela as bases necessárias para seu suporte, num processo que vincula imensamente a capacidade de recordação.

Para ilustrar este mecanismo de rememoração coletiva, Benjamin invoca os dias de festa, as datas comemorativas de um calendário, quando se tem a explosão deste contínuo da história, condensando-se numa data todo o passado que justifica sua importância. Com esse exemplo é feita a diferenciação entre o tempo contado pelo relógio e aquele que é dividido pelo calendário, pois no primeiro caso, teríamos tão somente a acumulação dos 
momentos como se eles pudessem ser reduzidos a dados computáveis e uma vez ocorridos, para sempre sepultados. Este seria o caso classificado por Benjamin como tempo homogêneo e vazio, em oposição à segunda hipótese que seria a do tempo dividido pelo calendário, cuja possibilidade de dias de recordação dá a eles o predicado de "monumentos de uma consciência da história". ${ }^{13}$

Nota-se que nestes dias de feriado, as pausas que reúnem o fluxo temporal de forma que passado e presente se confundem são estudadas por Benjamin com a contribuição dada pelo filósofo Leibniz (1646-1716), no que tange ao conceito de mônada, recepcionando-o a partir de sua descrição como estrutura de qualidade múltipla e, simultaneamente, constituída como unidade simples e indivisível, de forma que "cada mônada representa todo o universo"14. Assim, Benjamin se apropria dessa definição para dar forma ao seu método historiográfico, na medida em que, nesta imagem da mônada, consegue projetar toda a história no momento presente, ou seja, os acontecimentos passados deixam de ser interpretados numa perspectiva historicista de acumulação, ganhando individualidade e, mais que isso, vivência contemporânea. Na explicação de Olgária Matos, temos que: "tal como a recordação (Eingedenken), a mônada histórica concentra o pensamento não apenas naquilo que "ocorreu alguma vez" e desapareceu, partiu, mas em algo que ocorreu como parte de um universo que ainda está aqui, agora." 15

Nestes termos, trata-se de buscar as correspondências historiográficas, captando imagens de um tempo potencialmente perdido encerrado nesta noção de mônada, valendo-se do recurso muito bem explorado por Proust, qual seja, a memória involuntária, de forma a se encontrar no presente, os excedentes de significado que não puderam se concretizar no passado, mas que permaneceram virtualmente como promessa de realização.

Para Walter Benjamin, nunca se tratou mesmo de conhecer o passado "[...] tal como ele propriamente foi[...]". ${ }^{16}$, mas sim de "[...] apoderar-se de uma lembrança tal como ela lampeja num instante de perigo[...]"17, ou seja, no instante em que ela é solicitada, pelas exigências históricas contemporâneas, como promessa de salvação. Nesse caso, parecenos que o primeiro esclarecimento relaciona-se com a descoberta de qual teria sido o "biscoito madeleine"18 que desencadeou em Benjamin o processo de rememoração do barroco, mais especificamente do drama barroco alemão do séc. XVII.

Abandonemos, para tanto, a concepção linear da história, fragmentando o tempo, para ser plausível pensar em termos de pré e pós-história, conceitos centrais em Benjamin, por aludirem ao tempo, embora escapem dele, dada a não inserção em um raciocínio sequencial. ${ }^{19}$ Exemplifiquemos dizendo que, para o autor, a pré-história do drama barroco seriam os diálogos socráticos, não a tragédia renascentista, como seria de se esperar, na lógica historicista. E isso pelo fato de encontrarmos nesses dois gêneros tão distantes no tempo, afinidades que permitem a rememoração recíproca.

Com isso, o alvo passa a ser a busca do que poderia haver de semelhante entre o séc. XVII e o atual, em suas representações. Ora, como já foi colocado, na metodologia benjaminiana, a análise tem como objeto o drama barroco, enquanto gênero literário, escolha possivelmente motivada pela eficiência da arte na exteriorização do espírito de uma época, tornando verificável como se deu a percepção humana diante da história, ou seja, possibilita o alcance da aura que cada período histórico projeta através de sua tradição e cultura.

Cadernos Benjaminianos, n. 3, Belo Horizonte, jan.-jun. 2011, p.105-124 
Ter a sensibilidade para de fato experimentar a época em que se vive é um privilégio bastante raro, exigindo um certo distanciamento psicológico das relações sociais, numa complexa vinculação daquele que está integrado, mas apenas de forma marginal, permitindo-lhe a apreciação de seu tempo, sem o elemento absoluto da identificação que torna deficiente a crítica. O outsider é assim pensado como o indivíduo a quem é dado o privilégio de contemplação do palco historicista, nas experiências coletivas que o constituem.

Nesse caso, este observador privilegiado perante uma alegoria barroca do aludido século, experimentaria de que forma o tempo histórico? A resposta a essa pergunta servenos também para explicar o porquê de vivenciarmos a pós-história daquele período. Entretanto, até mesmo esta solução é dada por Walter Benjamin na forma de alegoria, lançando-nos ainda uma vez no enigma da mônada que carrega em si a "[...]exposição barroca mundana da história como história mundial do sofrimento, significativa apenas nos episódios de declínio" ${ }^{20}$. Ou seja, trata-se de um tempo notadamente marcado pela falta de esperança, na consequente superposição da melancolia perante os demais humores, sendo esta uma característica da assimilação de um espaço que se revela a partir de ruínas, imagem indicativa de um mundo que se esfacela rapidamente, efêmero, tendente à morte e à destruição.

Já que essa descrição de fato não se distancia das projeções históricas do pós-guerra, quando ruínas espalhavam-se num cenário tendente à calamidade, num tempo de promessas liquefeitas, conclui-se que a comunicação entre o séc. XVII e o atual é favorecida porque ambas, em seus extremos, afirmam-se como épocas de decadência. Uma realidade desencantada, desprotegida do controle interventor dos deuses. Assim, esvaziada de transcendência e de utopias, a vida do homem no séc. XX, em igual medida a do barroco, evolui desamparada diante de um destino onipotente. A salvação, se houver, terá de ser profana, emergindo do controle humano ante a natureza decaída.

Ora, em Benjamin, o séc. XVII, a modernidade cartesiana, aparece como "Trauerspiel", substantivo traduzido para o português como drama barroco, melhor compreendido, entretanto, quando pensado originariamente em sua tradução literal, da qual descobriremos a justaposição de espetáculo ${ }^{21}$ e 1 luto ${ }^{22}$, portanto, o termo em si procura expressar, simultaneamente, ilusão e tristeza. Ideias estas que precisam ser consideradas em conjunto, pelo fato de explicarem-se reciprocamente. A melancolia confirma-se, assim, como imbricada no homem que contempla do interior o espetáculo da modernidade.

\section{As personagens na trama barroca}

A teoria do luto é bastante desenvolvida no Trauerspiel, sua interpretação é, portanto, necessária para que se compreenda a visão barroca da história. Assim sendo, partindo-se da morte do ente amado descobre-se no enlutado uma atitude mimética, ainda que inconsciente, uma busca pelo preenchimento do vazio deixado, através da identificação com aquele que tendo partido levou consigo também parte do seu vigor, na medida em que o luto se caracteriza por cores escuras, pela renúncia aos prazeres, enfim, pela morte simbólica do indivíduo.

Este estado de espírito refletindo-se na história traduz a visão do mundo do melancólico, daquele que sucumbe, levando consigo a natureza, tornando-a muda. Nas palavras de Benjamin, temos que: "Em todo luto existe uma tendência à mudez, que é 
infinitamente mais que a incapacidade ou a relutância de comunicar-se. (...) Quanto mais a natureza e a Antiguidade são vividas como culpadas, mais imperativa se torna sua interpretação alegórica, que representa apesar de tudo a única redenção possível”,23.

A história barroca, portanto, está marcada pela emergência da morte, enquanto conteúdo básico desta interpretação alegórica mencionada por Benjamin. Ao contrário da tragédia que concebia a possibilidade de redenção, no Trauerspiel, a história apreendida como natureza revela-se degenerada, decadente, marcada por ruínas e ossadas, pois tudo que é vivo tende à morte e já que é assim, tenta-se como última esperança a salvação por meio da alegoria, de tal modo que nesta formação complexa, quer-se esconder o segredo do seu significado, para que assim ele possa resistir à fugacidade do tempo.

É bastante significativa esta missão do alegorista, na medida em que ela oferece um antídoto à experiência do transitório, instrumentalizando a história como cenário, recuperando tudo que nela está morto e destruído, agindo, consequentemente, como um anjo da ressurreição, um criador terreno das coisas divinas, sendo este o máximo de esperança que se pode obter num mundo enlutado. Necessário, entretanto, atentar para esta condição, pois não se trata de uma salvação transcendental e sim humana, lembrando que os objetos aparentemente recuperados "se transformam em alegorias, e essas alegorias preenchem e negam o Nada em que eles se representam, assim como a intenção, em vez de manter-se fiel até o fim à contemplação das ossadas, refugia-se, deslealmente, na Ressurreição"24.

Opondo-se, então, a uma crença transcendental, a imanência afirma-se como notável característica da percepção historiográfica barroca. Contribui para que a sociedade do séc. XVII seja efetivamente secularizada, o que, em certa medida, pode-se entender como conseqüência irônica da Contra-Reforma, quando a imagem agostiniana da cidade de Deus é dissolvida. Perde-se, na busca pelo controle da sociedade, a crença em uma solução divina, substituída pela atuação do homem, que, agora em termos profanos, terá de reinar em meio a uma natureza ameaçadora.

Assim, a trama do drama barroco tem predileção pelo cenário da corte, escolhido para a caracterização das frágeis relações de poder, marcadas por desonestidade e improbidade, em que príncipes, cortesãos e papas se corrompem num jogo de intrigas. Demonstra, com isso, a instabilidade dos acontecimentos históricos encenados da forma como eram assimilados pelo olhar literário, sobretudo no que diz respeito à movimentação política, narrada a partir da história dos reis, soberanos absolutos deste palco.

Por este motivo, o Trauespiel recorrentemente revela a condição principesca como repleta de antíteses, justamente em razão de sua busca pelo controle da sociedade. Antíteses que orbitam o universo barroco, afinal de contas, este é o gênero que tenta expressar a falibilidade humana, e o faz a partir do ponto de vista daquele que, em certa medida, maneja o destino, o rei.

A missão de reinar, embora seja facilitada pelo poderes despóticos que lhe são imanentes, revela-se sempre dificultosa. Pois é justamente o monopólio da tomada de decisões que torna o príncipe um sujeito frágil, desprotegido numa tarefa tão arriscada, uma vez que bastaria um pequeno descuido para este sucumbir às ameaças conspiratórias. O dualismo próprio do barroco está presente também na caracterização do príncipe, de forma a torná-lo uma conjunção de tirano e de mártir, sendo estas "as faces de Jânus do monarca" ${ }^{\text {- }}$ - paradoxos, que, no entanto, se mostram conciliados em sua personalidade. Se no exercício de sua função o tirano/mártir tem o destino dos súditos em suas mãos, ao ordenar prisões e execuções, por outro lado não está totalmente a salvo, já 
que seu posto é alvo de inveja e intrigas. Em suma, não pode confiar em ninguém: encontra-se abandonado na solidão do poder despótico, sujeito (súdito) às consequências mais radicais de suas decisões.

A representação do monarca é realmente curiosa, pois a fonte de suas misérias é, a um só tempo, também o motivo de seu prestígio. Ainda que de sua condição principesca possa retirar os fundamentos de sua majestade, legitimando seus delírios, está mais exposto ao sofrimento, pois quando assume obrigações e papéis divinos, sem gozar dos tais poderes excepcionais, como a imortalidade e a onipresença, não consegue ter qualquer certeza da sabedoria de seus atos. A hesitação afirma-se como elemento importante da alma do tirano, que a experimenta mais do que qualquer outro indivíduo, sem poder demonstrá-la - senão por atitudes de extrema loucura que culminam na destruição de si e possivelmente de seu povo.

Trata-se, portanto, de uma falta de simetria entre o poder de governar que é de proporções divinas e a capacidade de executá-lo, dadas as limitações humanas. Ora, claro que em termos históricos, a imagem que se transmite é desoladora, pois se percebe a outorga de expectativas de salvação à forças terrenas que, naturalmente, não conseguem concretizá-las.

Nas palavras de Benjamin, temos que:

O que nos fascina, sempre de novo, na destruição do tirano é a contradição entre a onipotência e a objeção de sua personalidade, por um lado, e a convicção da época quanto à força sacrossanta de sua função, por outro. (...) se o déspota não fracassa apenas como pessoa, mas também como governante que exerce seu poder em nome da humanidade histórica, sua queda é também um julgamento, que atinge os próprios súditos. ${ }^{26}$

Outro personagem freqüente no Trauerspiel é o cortesão. Importante também que seja analisado, para que se perceba seu caráter igualmente dúbio e inconstante, de forma a buscar nas situações o maior proveito para si mesmo. Assim, ele é simultaneamente caracterizado como intrigante e como santo, encantando o espectador com seu conhecimento da alma humana, condição essencial justamente para conseguir manipulála. Trata-se, portanto, de um cérebro voltado para as maquinações políticas, esperto e astuto na execução de sua tarefa. Embora a decisão final caiba ao príncipe, são conhecidas as manobras dos cortesãos que foram essenciais para este desfecho, podendose dizer, na análise de Benjamin, que ele "interfere de forma imediata nos negócios do Estado, a fim de ordenar os dados do processo histórico numa sequência regular, harmônica, e por assim dizer espacialmente mensurável"27.

Quanto ao elemento de santidade presente no cortesão, este é informado em razão da necessidade de se manter uma rígida disciplina interna, para o exercício de suas incumbências, já que é um servo do monarca, compartilhando do seu sofrimento e hesitações, afastando-se das paixões mundanas, para se entregar ao conhecimento dos homens. A grande proximidade com o príncipe se por um lado é benéfica, por outro não é totalmente confiável, já que pode traí-lo ou envenená-lo, sempre que perceber ser esta a melhor alternativa política, por isso a tensão estar sempre presente no envolvimento de ambos.

Importante que se note, entretanto, que o traço comum entre o monarca e o cortesão é a melancolia, dada a influência comum de Saturno, o planeta estudado pelos gregos como

Cadernos Benjaminianos, n. 3, Belo Horizonte, jan.-jun. 2011, p.105-124 
o responsável pela secreção da bílis negra, através do baço, obscurecendo o humor do indivíduo, levando-o à estados de extrema tristeza. Neste caso, o desequilíbrio próprio destes personagens os torna vítimas deste humor. Quanto ao Príncipe, a incapacidade de tomar uma decisão nada mais é do que uma consequência da acedia saturnina, forte o suficiente para torná-lo apático e confuso, incapaz de agir afirmativamente, devido a esta paralisia simbólica do seu coração. O mesmo ocorre com o cortesão, cujo traço de infidelidade também pode ser compreendido como sintoma do humor melancólico, na medida em que esta bílis negra o torna mais sucetível, faz com que seu caráter seja permeável e vacilante, o que naturalmente favorece o cometimento da traição.

A corte onde vivem estes personagens é, portanto, o centro dos acontecimentos históricos, o local onde a ação de desenvolve. O cenário é essencial no drama barroco, em razão do enfoque dado às coisas que subjungam os homens. Mais uma vez se faz referência, portanto, à importância que tem a manifestação alegórica neste período. A corte é o espaço onde a salvação profana deveria se processar, por ser nela que as decisões são tomadas. Porém, é importante constatar que o mesmo espaço que deveria proporcionar a paz, realizando a justiça, serve também como palco para crimes, infâmias, enfim. Trata-se do lugar em que a ordem e o caos convivem antiteticamente.

\section{A história como espetáculo}

A intenção benjaminiana de caracterizar o Trauerspiel a partir da exposição de seus personagens é bastante significativa, afinal de contas, o resultado que se obtém é um painel no qual desfilam tipos humanos, montando-se, assim, o perfil psicológico da sociedade de então. Os estereótipos postos ajudaram Benjamin na compreensão da mentalidade que construiu o seu tempo, a saber, a modernidade.

Ou seja, é a preocupação com o presente histórico que levou Benjamin à decifrar o drama barroco alemão, como se consegue concluir também pela época na qual o autor dedicou-se a estas pesquisas que, aliás, foram apresentadas como requisito para se tornar livre-docente na Universidade de Frankfurt, muito embora tenham sido recusadas pelos examinadores, uma injustiça felizmente corrigida pela história. Enfim, trata-se de uma dissertação que se tornou pública em 1925, tendo sido, portanto, elaborada em um período que se encaminhava para o totalitarismo, sistema político marcado pelo controle.

Ora, Benjamin soube apreender a aura deste seu tempo, identificando sua semelhança com a idéia presente no Trauerspiel de um príncipe dominador que precisa sujeitar a natureza ameaçadora, levando-a ao progresso, fortificando, com isso, conceitos que a partir de então só iriam se expandir, paradoxalmente, dentro da procura por legalidade e produtividade.

É assim que a política do séc. XVII e a do séc. XX se assemelham, pois ambas se afirmam diante de uma realidade desencantada, no sentido da perda dos referenciais eternos, outrora associados à religião, pois ainda que, no Trauerspiel, não fosse o tempo de se anunciar a morte de Deus, podia-se desde então considerar a ausência da Graça, isso pela conversão da fé em Deus na adoração ao homem.

A tendência que hoje pode ser apontada com maior segurança, na medida em que se discute um acontecimento passado, foi justamente a de se afirmar a crença antropocêntrica lançada no mencionado sec. XVII, fundamentando, consequentemente, as bases para o Iluminismo, cujo apogeu se daria no século seguinte.

Cadernos Benjaminianos, n. 3, Belo Horizonte, jan.-jun. 2011, p.105-124 
Dessa forma, a representação da corte barroca ou do totalitarismo no séc. XX é montada como um espetáculo, já que, em Walter Benjamin, se prioriza a análise literária da história humana. Espetáculo que, entretanto, só consegue ser apreendido por aquele que conseguir distanciar-se de seu papel, contemplando-o. Assim sendo, a atuação de sujeito racional adequou-se melhor aos que não tinham a consciência dessa representação, em outras palavras, se o homem do Renascimento adaptou-se, o mesmo não pode ser dito do Barroco que, fraturado na duplicidade de alma e corpo, razão e religião, jamais constituiu uma unidade, senão a partir de fragmentos.

A consciência do jogo funciona, portanto, como motivo para a melancolia, já que não se trata de uma percepção elevada que liberta, mas de ilusões que são perdidas num universo secularizado. No drama barroco, personagens complexos, harmonizados pela justaposição de qualidades extremas e antitéticas, dão prova de uma realidade confusa que se pretendia controlar. O príncipe encenado, simultaneamente, nos papéis de tirano e de mártir, representou, como foi analisado, as contradições do período, sendo que, em harmonia com o gênero literário, também encontraremos correspondentes no direito e na filosofia.

Exemplifiquemos alegando que a tensão psicológica, enquanto componente básico do drama barroco, é notável na tarefa do príncipe, tal como foi também na missão de Ulisses, reinterpretada por Adorno e Horkheimer. ${ }^{28}$ Sendo ilustrada por Benjamin nas descrições das dúvidas de Hamlet, personagem descrito como "espectador das graças de Deus" ${ }^{29}$, muito embora elas lhe sejam insuficientes, já que está preocupado apenas com seu próprio destino.

Isso porque o príncipe deve ter êxito ao submeter a natureza externa, mas considerando que ele igualmente se submete a ela, sua missão abrange, inclusive, o controle de si. Nesse processo, tanto Ulisses quanto Hamlet passam por uma série de hesitações, a diferença está no fato de que o herói criticado por Adorno e Horkheimer, ao final, julgase vitorioso, ao passo que em Hamlet, a melancolia é o resultado mais evidente.

Dessa cisão entre o sujeito e a natureza é que emerge o impulso para dominá-la, sem se desconsiderar, como vimos, o domínio de si. Para a consolidação dessa proposta, evidentemente, o direito é um meio por excelência, sobretudo, na sociedade moderna, ocupando o lugar anteriormente preenchido pela magia, afirmando-se como uma variação da mesma, dada a forte carga simbólica que possui.

Sobre o simultâneo domínio da natureza exterior e interior, esclarece Benjamin:

A função do tirano é a restauração da ordem, durante o estado de exceção: uma ditadura cuja vocação utópica será sempre a de substituir as incertezas da história pelas leis de ferro da natureza. Mas a técnica estóica também dá forças para uma estabilização interna equivalente: o controle das emoções, num estado de exceção dentro da alma. ${ }^{30}$

Importante agora que se compreendam outras esferas do conhecimento, como é o caso da política e do Direito, nas quais são refletidos os propósitos de imanência e de controle da natureza que até agora foram analisados no Trauerspiel, acompanhando-se as intenções benjaminianas.

\section{Controle da natureza como propósito político do séc. XVII}

Cadernos Benjaminianos, n. 3, Belo Horizonte, jan.-jun. 2011, p.105-124 
Assim, pensando nos paralelos existentes entre o direito e a política, verifica-se que no séc. XVII, a política orientou-se pelas diretrizes apontadas pelo jusnaturalismo, de forma a se promover objetivos e finalidades, a partir dos quais se conseguisse agrupar os destinatários em torno do poder estatal. Em razão da feição jusnaturalista dos séculos XVII e XVIII, recorre-se na determinação dos fins aos caracteres próprios da natureza humana, de modo a se tomar o perfil natural do homem, em suas qualidades e limitações, com o intuito de presumir como seria possível atingir o alvo visado.

Para tanto, a lei natural facilmente pode ser convertida em um comando ordenador de condutas, isso é feito de modo presumidamente comparável a um silogismo, já que abriga relações de causa e consequência. A vinculação estabelecida entre meios e fins serve ao interesse do sujeito em relação a sua autopreservação. Nesse caso, a sociedade civil entendida como condição necessária para que o homem consiga resguardar seus próprios interesses torna-se imprescindível.

Ora, não sendo possível apelar aos deuses, é perdida toda a relação de causalidade entre os destinos humanos e a transcendência, refletindo-se no governante as expectativas de proteção contra uma natureza tendente à calamidade. A consequente concessão de poderes temporais ao príncipe reproduz na terra a perspectiva de estabilidade, outrora crível no aspecto religioso. Trata-se como foi visto, da imanência como notável característica do século barroco, no qual se deu o desenvolvimento da filosofia política de Hobbes, autor representativo das expectativas do período.

Para, então, exemplificar a aproximação entre o modelo jusnaturalista e o fundamento do Estado, recorre-se a Thomas Hobbes (1588-1679), cuja ideia central remete à busca de unidade contra a anarquia. De forma que, como se pode conferir no transcorrer da leitura do Leviatã, no estado de natureza, por usufruírem os homens de igualdade de fato e de liberdade, haveria permanentemente a ameaça de guerra, uma vez que as paixões humanas contribuiriam para esse desfecho, num cenário de escassez de recursos. ${ }^{31}$

A imagem descrita foi uma constante no pensamento hobbesiano e deve ser interpretada como uma maneira metafórica de se apontar os riscos da guerra civil, sendo esta uma preocupação justificável, em razão do contexto político em que estava inserido, qual seja, a eclosão da Guerra Civil Inglesa (1642-1649).

A razão foi exaltada, pelo autor, como possibilidade de redenção daquele estado de natureza, isso pelo desenvolvimento de regras prudenciais, considerando-se, para esse fim, todos os homens dotados da mesma racionalidade, de forma a se aproveitar os cálculos úteis para inferir os meios associados ao interesse de sobrevivência. Hobbes fez dessas regras de prudência um nome alternativo para as leis naturais, confirmando, assim, a necessidade do Estado, enquanto instituição dotada de força, capaz de lhes assegurar eficácia.

Da constatação dos prejuízos consequentes do estado de natureza, teríamos homens concordantes sobre o carecer de uma estruturação estatal. Esse acordo precisaria ser ratificado pela maioria, em caráter permanente. Em resumo, trata-se do consenso prévio para a fundação da sociedade civil. A proposta traz consigo a obrigação de renunciarmos ao poder que nos é intrínseco, em benefício de transferi-lo para uma única pessoa, seja ela física ou jurídica.

Em Hobbes, a própria vontade do homem delimitaria o que se poderia definir por justo ou injusto, descartando-se, portanto, valores absolutos. A ética oscilaria conforme fosse conveniente. Deste desamparo, conclui-se o modelo jurídico por ele adotado, afinal de 
contas, a rigidez necessária para a segurança só seria possível pela dogmática construída por um legislador estatal.

Tal a base de fundamentação do absolutismo, a partir da defesa da soberania consubstanciada nas prerrogativas de ser irrevogável, indivisível e absoluta, sendo esta a forma de governo preponderante no séc. XVII, confirmando a pretensão barroca de se estabilizar a sociedade pela política, fornecendo-se a solução profana.

Nas palavras de Benjamin, temos que:

É nesse tempo que estão inscritos não somente a vida orgânica dos homens, como as manobras do cortesão e as ações do Príncipe, que segundo o modelo de um Deus que governa, intervindo em ocasiões específicas, interfere de forma imediata nos negócios do Estado, a fim de ordenar os dados do processo histórico numa sequência regular, harmônica, e por assim dizer espacialmente mensurável. ${ }^{32}$

Entretanto, o homem barroco reconhece que a imanência é apenas um artifício para satisfazer seu desejo de salvação, a alegoria compreendida como "[...] único divertimento, de resto muito intenso, que o melancólico se permite [...] ${ }^{33}$ vem como tentativa de transcendência, mas uma tentativa que, todavia, não consegue romper com a forte carga de ilusão que carrega, na medida em que sua temporalidade está conectada a do alegorista, em cujas “[...] mãos, a coisa se transforma em algo de diferente, através da coisa, o alegorista fala de algo diferente, ela se converte na chave de um saber oculto, e como emblema desse saber ele a venera [...]"34.

Assim, a busca de um reino estável que se contraponha a esta "[...] época inebriada de crueldades, imaginárias ou vividas" ${ }^{35}$ revela-se, em última instância, como exercício da imaginação na busca de um outro lugar, permitindo que a história se reflita nos palcos, com toda a transitoriedade e fragmentação que lhe caracterizam, de maneira a traduzir os acontecimentos de declínio pelas imagens que lhe dão forma, quais sejam, as ruínas. $\mathrm{O}$ barroco adora a ruína, na medida em que elas se afirmam como uma forma de resistência e são demonstrativas do efêmero, por meio do qual "[...] o olhar saturnino daquelas gerações reconhecia a história"36.

A salvação pela transcendência é, portanto, mais uma alegoria, mais uma fantasmagoria do drama barroco, uma tentativa frustrada de estabilização histórica, presente também no direito, campo de atuação do Príncipe, pois como assegurou Atger, citado por Benjamin, temos que: “[...] o Príncipe desenvolve todas as virtualidades do Estado por uma espécie de criação contínua. O Príncipe é o Deus cartesiano transposto ao mundo político." ${ }^{37}$ Podemos, assim, atribuir ao príncipe o papel também de alegorista, na medida em que atua concedendo significação ao alegórico, o que, nesse caso, é particularmente essencial, pois está vinculado à legitimação do seu poder, por isso Benjamin afirmar que "[...] ge gesto que procura apropriar-se da significação é idêntico ao que procura distorcer violentamente a história”38.

\section{O controle da história-destino}

Dada a forte correspondência entre o direito e literatura, por serem campos que trabalham fortemente com as paixões humanas, perceberemos a coincidência das produções no período, uma vez que se no drama barroco as personagens orientavam-se 
em razão da perplexidade perante a natureza, de forma a buscarem seu controle, sua regulamentação, como meio de solução profana, temos semelhante propósito compartilhado pelo direito, orientado, em grande medida, pela filosofia cartesiana.

Assim, representando o espírito de dualidade barroco, encontraremos René Descartes (1596-1650), graças a ele, o pensamento abstrato foi reconhecido e desligado da matéria, sendo por si mesmo capaz de inferir conhecimentos válidos. O universo, na escola cartesiana, foi então dividido em dois domínios independentes: a esfera espiritual e a espacial.

Desse sistema racionalista, inferiu-se que na tarefa de pensar pode-se descobrir proposições eternamente válidas sobre o que é humano e divino, havendo, consequentemente, uma crença no mundo, enquanto estrutura estática.

O método cartesiano, dando base a esse sistema, influenciou a evolução do pensamento jurídico, consubstanciado na descrença perante os dados sensoriais e a dialética escolástica, ou seja, orientava-se por veredas que desprezavam o que não pudesse ter o grau de certeza matemático. Graduando-se por intuições que levariam ao resultado pretendido, o de ideias claras.

A verdade, enquanto dado a ser obtido, viria como consequência de um método ordenado paulatinamente, sem que houvesse recuo ou avanço excessivo, tudo em torno do importante conceito de ordem. ${ }^{39}$

O campo jurídico moderno foi representado, em grande parcela, nessa perspectiva cartesiana, da qual retiramos a impossibilidade de um direito natural extraído da observação da natureza, afinal de contas, para Descartes, espírito e matéria separam-se. Além de garantir-se a produção de axiomas, orientados por aquela mesma noção de ordem.

Muitos juristas, seguindo essa vertente, procuraram justificar-se em princípios ditos racionais, num caminho formado por deduções e inferências. O direito, portanto, estaria situado como registro do pensamento e sua acessibilidade dependeria desse método dedutivo capaz de inferir regras. Essa corrente usurpa o nome Direito Natural, para agora tratá-lo como fruto da razão, desligando-o da natureza.

O racionalismo jurídico, com essa herança, tentará concretizar-se num sistema de regras jurídicas pretensamente universais e imutáveis, como se ele pudesse ser garantido pelo pensamento puro.

Em razão da separação da alma e do corpo, podia-se também preferir a relação do direito com a matéria, colocando-o como representação das paixões humanas, num aspecto vinculado à compreensão física dos fatos, regidos por leis mecânicas. Claro que tal vertente carrega, intrinsecamente, problemas de difícil resolução como o de pensar demasiado o direito como se ele pudesse ser obtido da mesma forma que as ciências naturais.

Percebemos, assim, a influência da percepção da história como destino também no ânimo jurídico, na medida em que o direito está vinculado aos propósitos do príncipe de ordenar a natureza, entendida como história, controlando-a, tal como é mostrado no Trauerspiel.

O desejo comum é o de estabilizar a natureza, silenciando-a em um modelo, no qual procura-se antever os resultados, extinguindo-se o elemento surpresa. A tentativa é a de se eliminar o sofrimento, na busca profana de solucionar o caos imperante nos períodos históricos de decadência, pois "[...]como declínio, e somente com ele, acontecimento 
histórico diminui e entra no teatro" ${ }^{\text {, }}$, nas tantas formas de encenações que reconhecemos, sejam elas legítimas ou não.

A racionalidade jurídica desse período teve fiel representação em Hugo Grócio (15831645), cuja obra orientou-se em direção ao rigor dedutivo e demonstrativo, com o qual o autor pretendeu construir seu método. Nos anos seguintes, Pufendorf, Espinosa, Leibniz e Cristian Wolff permaneceram concordantes com esse mesmo proceder.

Trata-se de um pensamento desenvolvido ao redor de um conceito de racionalidade triunfante que prefigurava a autonomização da normatividade jurídica.

Nesse sentido, Gottfried Wilhelm von Leibniz (1646-1716) projetou seus estudos de forma a defender o cálculo lógico ao invés de argumentos verbais incapazes de assumir uma característica universal. A razão, para ele, deveria estar comprometida com uma dupla função, a saber, deveria revelar o que poderia haver de insuficiente na compreensão do método jurídico, bem como, ser a base por cima da qual se projetaria o conteúdo do direito.

Discípulo de Leibniz, Cristian Wolff (1679-1754) também posicionou-se contra as modalidades de irracionalismo, de maneira a qualificar a estrutura normativa por seu valor uno e integral. Na mesma direção apontada pelos demais, esse autor tornou absoluta a racionalidade.

No jusnaturalismo de então, merece destaque Samuel Pufendorf (1632-1694). Sua contribuição foi condizente com o espírito da época, tanto assim que o seu pensamento condensou-se na esperança de dar ao universo jurídico uma forma racional e sistemática, num impulso de rigorosa cientificidade, valendo-se, com esse propósito, não apenas do método racional, mas também da pesquisa experimental que deveria complementá-lo.

Temos, portanto, com as diversas correntes que se seguiram a partir das considerações desses pensadores, a projeção de um racionalismo triunfante na satisfação de si mesmo.

No início da Idade Moderna, o direito natural vinha como agrupamento de leis referentes às condutas humanas, que estando em paralelo com as leis universais, ficariam da mesma forma inscritas na ordem do universal. Consequentemente, o acesso a elas só poderia ser assegurado pela razão. Não é o homem quem formula o direito, mas cabe exclusivamente a ele a capacidade de encontrá-lo.

Da posterior evolução desse princípio, temos, progressivamente, o direito natural desprendendo-se de sua participação na ordem cósmica, para prestar seu papel de instrumento regulador da vida em sociedade.

Enfim, foram mitologias criadas pela mente humana, inebriada em suas luzes. Imagens do mosaico racionalista, que pretendendo a verdade no mundo do conhecimento, delinearam novos dogmas obcecados em sua autoconfiança geométrica.

\section{Constelação barroca e sua atualização}

O drama barroco pode ser compreendido como ideia, do que decorre a dimensão atemporal que certamente possui. Ora, essa caracterização é essencial para que possamos admitir sua atualização na história. Pensado, então, como ideia, o drama barroco relaciona-se com o séc. XVII de forma independente, expliquemos seguindo a analogia de Benjamin, segundo a qual, "[...] as ideias se relacionam com as coisas como as constelações com as estrelas [...]" conseguimos chegar a nenhuma conclusão definitiva sobre o movimento das estrelas, sua origem, suas leis, sendo sua própria existência de todo independente da ideia em questão, 
do que resulta que a constelação pode repetir-se no espaço infinitamente, sobrevivendo às estrelas.

Sendo assim, de que forma pode-se mensurar a vinculação das idéias com os fenômenos? Refletindo sobre esta pergunta que, para Benjamin, é essencial, tem-se a resposta oferecida pelo próprio autor, de forma a se pensar a idéia como universal, condição esta que nos permite considerá-la como interpretação objetiva dos fenômenos. Desse modo, se o séc. XVII existe independentemente do drama barroco, isso não nos impede de interpretá-lo como um conjunto de representações, fornecendo-lhe uma carga de significação que por aproximá-lo da idéia consegue salvá-lo num abrigo atemporal. Neste mesmo raciocínio, o drama barroco também é favorecido, afinal de contas, desenvolvendo a analogia benjaminiana, a constelação depende das estrelas para receber delas iluminação, por isso que sem os fenômenos as idéias são obscuras e carecem de representação.

A ideia do drama barroco, então, aparece no séc. XVII, mas não exclusivamente nele. As características percebidas nos autores desse período são também encontradas, por exemplo, no drama expressionista. Essas características que foram definidas por Benjamin, tomando de empréstimo as observações de Victor Manheimer, feitas em 1904, de acordo com o qual: "Interiormente vazios ou profundamente convulsionados, exteriormente absorvidos por problemas técnicos e formais: assim foram os poetas barrocos, e assim parecem ser os poetas do nosso tempo, ou pelo menos aqueles que imprimiram em suas obras a força de sua personalidade [...]"42.

As afinidades presentes nos dois gêneros literários podem ser compreendidas como reflexivas da forma como o próprio tempo histórico era pensado, do que decorre mais uma vez o enigma do ciclo, pois não estando as ideias presas a um determinado contexto, as atualizações que delas fazemos demonstram que, de certa forma, estamos vinculados ao passado e, por esse mesmo motivo, quando pudermos redimi-lo também o presente se beneficiará.

Para Benjamin, não apenas o barroco, mas também o expressionismo emergiu de um contexto histórico marcado pela decadência, de forma que o intérprete desses acontecimentos, o poeta-escritor, reproduz num estilo violento, a violência que experimenta em sua vida. Trata-se, portanto, de um processo de exteriorização do caos que encontra dentro de si, muito embora também fosse verdadeiro dizer que, pela escrita, o poeta interioriza todo o caos que encontra no contexto que o envolve, razão pela qual sua arte emerge como necessidade. Nas palavras do autor, temos que: "Como o expressionismo, o Barroco é menos a era de um fazer artístico, que de um inflexível querer artístico."43

Para ilustrar a assimilação do expressionismo, podemos recorrer a Franz Kafka, aliás, fazer isso é seguir os passos indicados por Benjamin, quando no texto escrito para homenagear o autor pelo décimo aniversário de sua morte, fez a representação de sua obra, a partir da comparação com os quadros de El Greco, pintor do séc. XVII, encarado como padroeiro dos expressionistas, mostrando como ambos são parecidos na produção alegórica, na encenação, cada qual em sua esfera, do espetáculo do mundo, ressaltando o aspecto fragmentário e confuso da realidade e, portanto, também de seu estilo ${ }^{44}$.

$\mathrm{Na}$ obra kafkiana, o direito ocupa certamente uma posição de destaque, na medida em que pode ser associado à dimensão da culpa, do destino inexorável, mas, sobretudo, de uma força imanente que atua em conluio com o destino, pela inexistência da 
possibilidade de fuga, de forma que sendo a sujeição inevitável, a esperança, se houver, abriga-se fora desse mundo, sendo inútil todo esforço para acessá-la.

Na dimensão do direito natural, estudada anteriormente a partir da influência cartesiana no jusnaturalismo, a lei não escrita coincide com esse cenário misterioso, no qual o réu é acusado sem saber o porquê ou por quem. A pena aparece, então, como elemento catalisador da culpa sempre presumida.

Em Kafka, segundo Benjamin, a jurisdição “[...] remete a uma época anterior à lei das doze tábuas, a um mundo primitivo, contra a qual a instituição do direito escrito representou uma das primeiras vitórias" ${ }^{~} 45$. Nem por isso, entretanto, a situação tornou-se melhor ou mais acolhedora, pois, para esse autor, “[...] o direito escrito existe nos códigos, mas eles são secretos, e através deles a pré-história exerce seu domínio ainda mais ilimitadamente." 46

A obra de Kafka demonstra assim a construção do direito na esfera de influência barroca, fornecendo-nos um indicativo da atualidade dessa ideia, verdadeira para esse autor e igualmente lúcida para nós, por isso buscarmos nesse período os fundamentos da nossa própria época.

Vivenciamos a frustração kafkiana perante um modelo jurídico que pretendendo emergir como solução profana não teve êxito na concessão de respostas positivas duráveis. O ser humano descoberto da condição que outrora o exaltava, enfrenta a percepção de sua fraqueza, dos seus medos perante uma natureza que permanece, embora todos os esforços, desconhecida. Por isso sentir-se confuso, diante de tantos obstáculos interpostos a essa tarefa, grandiosos demais para um pensamento revelado em suas tramas facilmente corruptível.

Caminhos percorridos pelo cumprimento de revelações provenientes de intuições religiosas ou minuciosamente definidos pelo cálculo matemático endereçaram-se a respostas ingênuas, quando apreciadas valendo-se da memória. Mais do que a análise das respostas, não se consegue um julgamento claro sequer sobre a coerência das perguntas, uma vez que os contextos em que elas emergiram já não estão presentes da mesma forma. Talvez tenha-nos faltado determinação para encontrá-las, uma vez que lançamos projetos e os encerramos, sem ter certeza sobre sua efetiva realização, havendo ainda a possibilidade de que estejamos mesmo fadados a uma procura desprovida de fim, até porque, caso houvesse um término, aceitaríamos a noção de que a história é uma linha reta passível de extinguir-se.

De toda forma, com o estudo do drama barroco, Walter Benjamin, nosso alegorista, nos proporcionou a imersão simultânea no universo do séc. XVII e do séc. XX, nas décadas que marcaram o período entre guerras. Descrevendo-nos um tempo que desaba em ruínas, inóspito para os santos redentores. Benjamin, nosso anjo, nos ensinou como redimir o presente, a partir da contemplação das imagens que nos antecedem, vencendo a tempestade do progresso. Trata-se de contemplação ativa, pois na criação alegórica o que se faz é obra divina, cabendo-nos, por isso, o exercício da salvação.

No direito, a justiça não é transcendente, como nos ensinou Kafka. Ilusório é todo conhecimento que pretender livrar-nos do mal do mundo, porque, em última instância, mesmo esse mal é um saber alegórico, elaborado pelo próprio homem, seguindo-lhe na transitoriedade. Trata-se, portanto, de uma criação da mente que com ela se extingue. $\mathrm{O}$ direito, abrigo das significações, protege-nos produzindo também outras variedades alegóricas, entre as quais, a espada da Themis, imagem indicativa do poder e do controle da sociedade. 
Ora, nesse tempo abandonado pelos deuses, o que pode existir além das alegorias? Essa resposta não nos é concedida por Benjamin e com isso o enigma do ciclo nos embaraça com a insistência do seu retorno, encerrando-nos na expectativa de sua equação pelo uso dos materiais potencialmente úteis para seu cálculo, espalhados pelo chão aguardando a serventia igualmente alegórica que pudermos lhes conceder, rompendo-se, desse modo, dialeticamente com o tempo cíclico, a partir do instante em que experimentarmos a rememoração, por meio da qual se possa enfrentar os desafios presentes encerrados no passado, completando-se, enfim, a tarefa de nosso anjo, despertando os mortos e recolhendo os destroços, redimindo o presente, quando se atenta para os apelos do passado.

Abstract: The present paper intends to study the relationship between law and literature, having as reference the work by Walter Benjamin The origin of german tragic drama - Trauerspiel, in order to see how the baroque ideia, marked by the loss of transcendence and by the search for profane solution, in Prince's acts, influenced both the 17 th century as the present, given the similarities that allow mutual remembrance.

Keywords: Allegory. Law. History. Immanence. Literature. Modernity.

\section{Referências Bibliográficas}

ADORNO, T.; HORKHEIMER, M. Dialética do esclarecimento: fragmentos filosóficos. Tradução de Guido Antonio de Almeida. Rio de Janeiro: Jorge Zahar, 1985.

ALMEIDA, Jorge de; BADER, Wolfgang (Orgs). Pensamento alemão no séc. XX: grandes protagonistas e recepção no Brasil. São Paulo: Cosac Naify, 2009.

BENJAMIN, W. Obras escolhidas I: magia e técnica, arte e política. 7. ed. Tradução de Sérgio Paulo Rouanet. São Paulo: Brasiliense, 1994a.

Origem do drama barroco alemão. Tradução de Sérgio Paulo Rouanet. São Paulo: Brasiliense, 1984.

DESCARTES, R. Discurso sobre o método: para bem conduzir a própria razão e procurar a verdade nas ciências. In: Discurso sobre o método. DESCARTES ed. Tradução de Jacó Guinsburg e Bento Prado Jr. São Paulo: Abril, 1983. (Os pensadores).

GOYARD-FABRE, S. Filosofia crítica e razão jurídica. Tradução de Maria Ermantina de Almeida Prado Galvão. São Paulo: Martins Fontes, 2006.

HOBBES, T. Leviatã. Tradução de João Paulo Monteiro e Maria Beatriz Nizza da Silva. São Paulo: Abril Cultural, 1999.

JAEGER, W. Paideia: a formação do homem grego. Tradução de Artur M. Parreira. São Paulo: Martins Fontes, 2003

Cadernos Benjaminianos, n. 3, Belo Horizonte, jan.-jun. 2011, p.105-124 
KELLER, A. J. Michaelis: dicionário escolar de alemão. São Paulo: Melhoramentos, 2002.

LEIBNIZ. A monadologia e outros textos. Tradução de Fernando Luiz Barreto Gallas e Souza. São Paulo: Hedra, 2009.

LÖWY, M. Walter Benjamin: aviso de incêndio - uma leitura das teses "sobre o conceito de história”. Tradução de Wanda Nogueira Caldeira Brant. São Paulo: Boitempo, 2005.

MATOS, Olgária. O Iluminismo Visionário: Benjamin, leitor de Descartes e Kant. São Paulo: Brasiliense, 1993.

. Os arcanos do inteiramente outro. São Paulo: Brasiliense, 1989.

PLATÃO. As leis. Tradução de Edson Bini. São Paulo: Edipro, 1999.

PROUST, M. No caminho de Swann. Tradução de Fernando Py. São Paulo: Folha de S. Paulo, 2003

SCHOLEM, G. Walter Benjamin: a história de uma amizade. Tradução de Geraldo Gerson de Souza, Natan Nobert Zins e J. Guinsburg. São Paulo: Perspectiva, 2008.

VILLEY, M. A formação do pensamento jurídico moderno. Tradução de Claudia Berliner. São Paulo: Martins Fontes, 2005.

\section{Notas}

1 Sobre isso, Platão comenta: "Se descrevermos ambos como movendo regular e uniformemente num lugar idêntico, em torno das mesmas coisas e relacionados às mesmas coisas, de acordo com uma única regra e sistema - a razão, nomeadamente, e o movimento revolvente em um lugar (assemelhado ao revolver de um globo giratório) jamais nos arriscaremos a nos condenarmos à inabilidade para construir belas figuras de linguagem".

2 Sobre a divindade dos planetas, descreve Platão: "O ateniense: No que diz respeito a todos os astros e a Lua, e no que tange aos anos, meses e todas as estações, o que nos caberia fazer senão essa mesma afirmativa, a saber, que já que ficou demonstrado que são todos movidos por uma ou mais almas, que são dotadas de todas as virtudes, declararemos que essas almas são deuses, seja porque atuam de qualquer outra forma que se o queira. Será possível encontrar alguém que admita essa causalidade e, todavia, negue que 'tudo está repleto de deuses'? (Ibid., p. 418).

3 Conforme Werner Jaeger: "É certo que antes de Platão a língua grega não usa o termo cosmos neste sentido de ordem legal interior da alma; conhece, porém, o adjetivo kosmios, para exprimir uma conduta refletida e disciplinada. Também a lei de Sólon falava de eukosmia da conduta pública dos cidadãos e principalmente da juventude." (JAEGER, Werner. Paidéia: a formação do homem grego. 2. ed. Tradução de Artur M. Parreira. São Paulo: 2003. p. 678).

4 Conforme Platão: "O ateniense: Se, meu bom senhor, estamos na iminência de afirmar que todo o curso e movimento do céu e de tudo que ele contém detêm um movimento semelhante ao movimento, à revolução e aos raciocínios do intelecto e procedermos de maneira idêntica, claramente teremos que afirmar que a melhor alma governa a totalidade do universo e o conduz em seu curso, que é o do tipo descrito [e perfeito como ela]." (PLATÃO, 1999, op. cit., p. 415).

5 JAEGER, Werner, 2003, op. cit., p. 309. 
6 LÖWY, M. Walter Benjamin: aviso de incêndio - uma leitura das teses "sobre o conceito de história". Tradução de Wanda Nogueira Caldeira Brant. São Paulo: Boitempo, 2005. p. 41.

7 BENJAMIN, W. Origem do drama barroco alemão. Tradução de Sérgio Paulo Rouanet. São Paulo: Brasiliense, 1984. p. 164.

8 Ibid., loc. cit.

9 Id. Tese II sobre o conceito de história. In: LÖWY, M., 2005, op. cit., p. 48.

10 Id. Tese XIV sobre o conceito de história. In: Ibid., p. 119.

11 Ibid., loc. cit.

12 GAGNEBIN, Jeanne-Marie. Walter Benjamin: estética e experiência histórica. In: ALMEIDA, Jorge de; BADER, Wolfgang (Orgs). Pensamento alemão no séc. XX: grandes protagonistas e recepção no Brasil. São Paulo: Cosac Naify, 2009. p. 145.

13 BENJAMIN, W. Tese XV sobre o conceito de história. In: LÖWY, M., 2005, op. cit., p. 123.

14 LEIBNIZ. A monadologia e outros textos. Tradução de Fernando Luiz Barreto Gallas e Souza. São Paulo: Hedra, 2009. p. 36.

15 MATOS, C. F. Olgária. Os arcanos do inteiramente outro. São Paulo: Brasiliense, 1989. p. 32.

16 BENJAMIN, W. Tese VI sobre o conceito de história. In: LÖWY, M., 2005, op. cit., p. 65 .

17 Ibid., loc. cit.

18 Na obra de Proust, "No caminho de Swann", o autor descreve uma série de lembranças desencadeadas pela degustação de biscoitos madeleines, como podemos apreender do seguinte trecho: “(...) levei à boca uma colherada de chá onde deixara amolecer um pedaço de madeleines [...] Certamente, o que palpita desse modo dentro de mim deve ser a imagem, a lembrança visual, que, ligada a esse sabor, tenta segui-lo até mim." (Proust, 2003. p. 48-49).

19 Em uma conversa com seu grande amigo Scholem, importante aspecto do pensamento benjaminiano foi revelado, como se apreende da seguinte passagem: "Naturalmente, tudo isso estava bastante relacionado com seu interesse pela filosofia da história. Discutimos a esse respeito durante uma tarde inteira, no tocante a uma difícil observação sua de que a sucessão dos anos podia ser contada, mas não enumerada. Isso nos levou ao significado de sequência, número, série e direção. Será que o tempo, que certamente é uma sequência, tem também uma direção? Respondi que não tínhamos meios de saber se o tempo não se comporta como certas curvas que demonstram uma sequência constante em todos os pontos, mas não têm uma tangente em ponto algum, ou seja, não tem uma direção determinável. Discutimos se os anos, como os números, seriam intercambiáveis, assim como são enumeráveis." (SCHOLEM, 2008. p. 41).

20 BENJAMIN, 1984, op. cit., p. 188.

21 De acordo com o dicionário, a palavra Spiel é definida como: 1. jogo, partida, brincadeira. 2. apresentação teatral, peça, atuação artística. 3. execução de música. (KELLER, 2002. p. 258).

22 Também de acordo com o dicionário, por Trauer temos: 1. tristeza, dor. 2. luto. (KELLER, 2002, p. 273).

23 BENJAMIN, 1984, op. cit., p. 247-248.

24 Ibid., p. 255

25 Ibid., p. 93

26 Ibid., p. 95.

27 Ibid., p. 119

28 Referência à produção conjunta da obra "Dialética do esclarecimento", por Adorno e Horkheimer (1985).

29 BENJAMIN, 1984, op. cit., p. 180.

30 Ibid., p. 97. 
31 Cf. HOBBES, T. Leviatã. Tradução de João Paulo Monteiro e Maria Beatriz Nizza da Silva. São Paulo: Abril Cultural, 1999.

32 BENJAMIN, 1984, op. cit., p. 119.

33 Ibid., p. 207.

34 Ibid., p. 205-206.

35 Ibid., p. 206.

36 Ibid., p. 201.

37 “[...] le Prince développe toutes les virtualités de l'État par une sorte de création continue. Le Prince est le Dieu cartésien transposé dans le monde politique." de ATGER, Frédéric. Essai sur l'histoire des doctrines du contrat social. Thèse pour le doctorat. Nimes, 1906, p. 136 apud BENJAMIN, 1984, p. 119.

38 Ibid., p. 232.

39 Cf. DESCARTES, R. Discurso sobre o método: para bem conduzir a própria razão e procurar a verdade nas ciências. In: Discurso sobre o método. DESCARTES

3. ed. Tradução de Jacó Guinsburg e Bento Prado Jr. São Paulo: Abril, 1983. (Os pensadores).

40 BENJAMIN, 1984, op. cit., p. 201.

41 Ibid., p. 56.

42 MANHEIMER, Victor. Die Lyrik des Andreas Gryphius. Studien und Materialien. Berlin, 1904. p. XIII apud BENJAMIN, 1984, op. cit., p. 77.

43 BENJAMIN, 1984, op. cit., p. 77

44 Cf. Id. Franz Kafka: a propósito do décimo aniversário de sua morte. In:

Obras escolhidas vol. 1: magia e técnica, arte e política. 7. ed. Tradução de Sérgio Paulo Rouanet. São Paulo: Brasiliense, 1994a. p. 147.

45 Ibid., p. 140.

46 Ibid., loc. cit. 